\title{
Financial subsidies and the location decision of solar power plants in Hungary: An empirical investigation
}

\begin{abstract}
Mihály Lados Recent years have witnessed a significant
Centre for Economic and Regional

Studies, Hungary

Széchenyi István University,

Hungary

E-mail:ladosm@rkk.hu

Éva Szabina Somossy

Hungarian Energy and Public Utility

Regulatory Authority

E-mail: somossye@mekh.hu

Tamás Tóth

Hungarian Energy and Public Utility

Regulatory Authority

E-mail: totht@mekh.hu

Keywords: installation factors,

location factors, operational support,

financial support, solar power plants, renewable investments, renewable policies, renewable subsidies

increase in the number of solar power plants worldwide, including in the European Union. In Hungary, solar capacities have increased tenfold in the past three years, primarily due to the lower cost of solar technology and the favourable investment environment. The integration of these weather-dependent power plants into the electricity system, hitherto, has not been a problem in Hungary. However the expected increase in capacity over the next decade may cause grid problems, implying that the decision about the location of solar power plants is not a secondary issue. Hence, this study examines the factors that impact investors' choice of the optimal installation site and the extent to which financial assistance, primarily operating support, influence this installation decision. This type of research has not yet been undertaken in the Hungarian context. Therefore, our research - based on a questionnaire survey conducted in March 2018 - fills an important gap. In contrast to the conclusions of the extant literature covering other countries, in the case of solar power plants in Hungary the installation location is not based on natural factors (e.g. irradiation) but on the marketability and price of electricity - classified in the financial support category - as well as the network connection options. Additionally, operating support may influence the location of solar power plant installation, which can be used as valuable information for regulation in the course of further expansion of the domestic photovoltaic power generation.
\end{abstract}




\section{Introduction}

Current international trends show that solar panels are the most widely distributed renewable technologies globally, mainly due to technological cost reductions (Müller-Frączek 2019). In 2018, at 24\%, the growth in solar capacity was the highest among all renewable technologies (IRENA ${ }^{1}$ 2019). This trend is also evident in the European Union with solar capacity increasing by 61\% in 2018 (Agora Energiewende 2019).

In Hungary, expansion in solar power is a recent phenomenon with the installed capacity approaching 1000 MW by the end of 2019 (Figure 1). This increase has primarily been due to three reasons: the fall in the $\mathrm{LCOE}^{2}$ costs below the subsidised price level, favourable financing environment (low loan interest rate), and the abolition of the previous feed-in-tariff system, which increased the support applications by the solar power plants to obtain favourable subsidy conditions.

Based on the new energy strategy, domestic installed solar capacity is expected to exceed 6,000 MW by 2030 and to be close to $12,000 \mathrm{MW}$ by $2040 .^{3}$

Figure 1

\section{Changes in the built-in capacity* of solar power plants in Hungary}

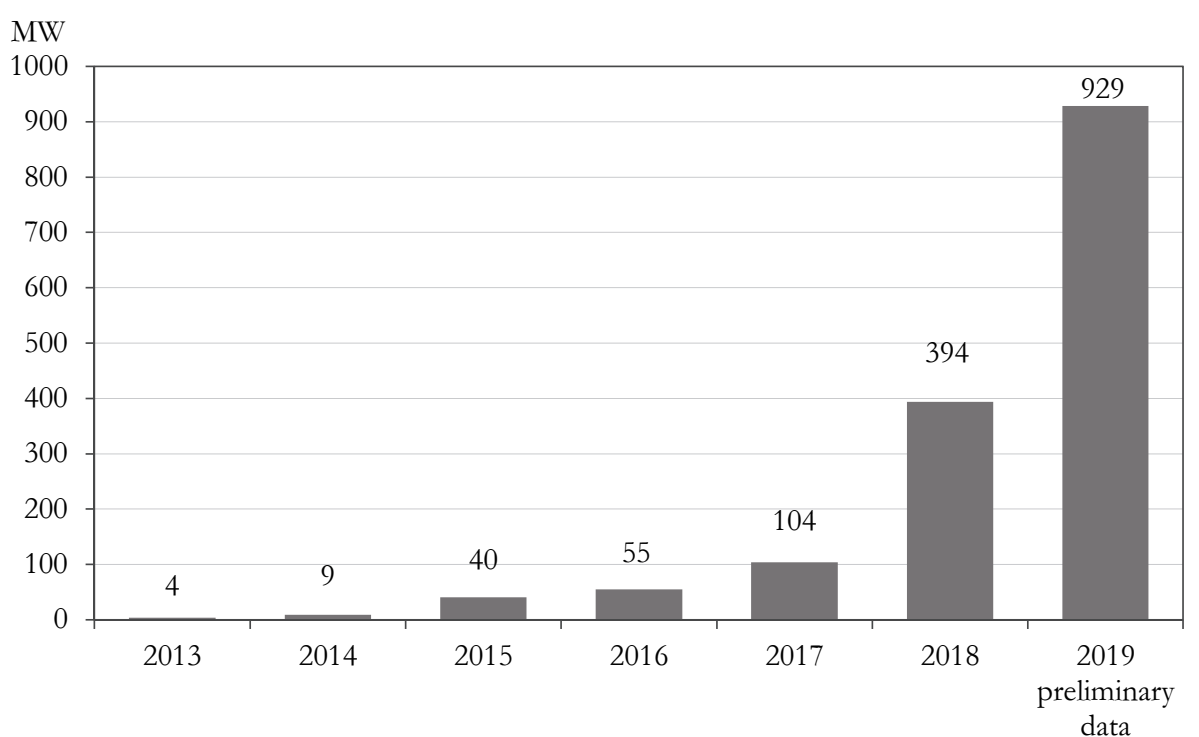

* Data for household sized power plants $(<50 \mathrm{~kW}$ built-in power capacity) is not included.

Source: Authors' elaboration based on data from the Hungarian Energy and Public Utility Regulatory Authority.

The spread of primarily decentralised solar power plants can be considered positive from climate protection, local job creation, and rural development points of

\footnotetext{
${ }^{1}$ International Renewable Energy Agency.

${ }^{2}$ Levelized Cost of Electricity.

${ }^{3}$ Magyarország Kormánya (2020).
}

Regional Statistics, Vol. 10. No. 2. 2020: 166-185; DOI: 10.15196/RS100207 
view. However, it is a major challenge for the basically centralised electricity systems to integrate them into the electricity networks and regulate the weather-dependent solar power generation (in the absence of adequate storage capacity). The question worth examining is whether support systems, especially operating support systems, could influence the location decisions for investment in solar power, and if so, to what extent.

In order to investigate this question, we conducted a questionnaire survey in March 2018 on renewable power plants in operation at that time, including solar power plants. Our objective was to identify the factors considered important by domestic solar power plant investors when making the installation decision, and the extent to which the presence of financial support (mainly operational support) changed their priorities.

\section{Overview of renewable and solar power plant installation factors}

In case of renewable power plants (biomass, biogas, solar, wind, hydro, and geothermal), the following groups of factors are generally considered decisive for the installation decision (they have different weights for different renewable technologies) $)^{4}$ :

- natural factors (e.g. meteorological factors, resource availability);

- infrastructure factors (e.g. network connection);

- economic factors (e.g. payback time, internal rate of return [IRR]);

- legal/regulatory/administrative factors (e.g. licensing circumstances);

- environmental factors (e.g. environmental impacts, land use); and

- social factors (e.g. social acceptance of the power plant, job creation).

According to the international literature, summarising case studies and practical experiences, eight sub-criteria can be defined within four criteria groups (climatological, topographical, localisation, and hydrological) for the selection of solar power plant sites.

In the case of photovoltaic solar power plants, the two main climatic factors that influence the performance of the modules are the irradiation level and temperature (Liu et al. 2017, Lee et al. 2017). The higher the level of irradiation, the more electricity is generated by photovoltaic installations (Al Garni et al. 2017, Ayag 2015). Furthermore, the capacity of the modules is significantly affected by temperature, as temperatures above 30 degrees Celsius reduce the amount of electricity generated, and in the long-run reduce the life and durability of the modules.

The topography of a given site should also be examined, which implies the elevation of the surface in the case of solar power plants. For photovoltaic

\footnotetext{
${ }^{4}$ For more information see Kyriakarakos et al. (2014).
} 
installations, a maximum surface elevation of $3 \%-5 \%$ is generally accepted, and thus, flat terrain is generally preferred. A higher surface elevation jeopardises the feasibility and increases the investment costs (Carrión et al. 2008).

An important group of criteria are the so-called locational factors, where the following conditions need to be examined: in the first place the proximity of existing road networks to ensure optimal transport conditions and maintenance of the modules and associated equipment (Sánchez-Lozano et al. 2015); secondly, the distance from populated areas in order to reduce network losses and the distance from electricity networks to minimise network connection costs (Uyan 2013); and thirdly, the factor closely related to the fourth set of criteria, namely the distance from the water bases. (Azevedo et al. 2017).

The fourth set of criteria are the hydrological factors, particularly important in areas with sparse vegetation. For instance, in Morocco: being close to the Sahara desert, and where the water demand for cleaning off the sand from solar panels is significant. Thus the proximity to rivers, dams, and groundwater bases may be a determining installation factor (Merrouni et al. 2018).

The above analyses, summarising practical experiences, generally do not consider the impact of subsidies on installation decisions, while other international studies (mainly those conducted by German researchers) have revealed a link between the location of renewable power plants and subsidies for the renewable electricity generation (Annex 2). Some of these are comprehensive analyses covering all renewable technologies (e.g. Polzin et al. 2015, Jägemann 2014), while others are specific to solar plants (Lüthi 2010; Annex 1) or focus on wind farms (Hitaj et al. 2014; Schmidt et al. 2013, Pechan 2017, Obermüller 2017, Hiroux-Saguan 2010).

In a comprehensive study, Polzin et al. (2015) examined the impact of certain renewable policies (e.g. fiscal and financial incentives, market incentives, and regulatory and political environment) on investments in renewable electricity generation capacities in case of institutional investors (e.g. investment and pension funds, banks, and insurance companies). The data included in the study were analysed for the Organisation for Economic Co-operation and Development (OECD) countries over a 12-year period (2000-2011), broken down by sectors: wind, solar, and biomass, and aggregated renewable capacity data, in a panel regression analysis. The dependent variable in the model was the aggregated newly installed renewable capacity (MW) in a given country, year, and sector, while the independent variable was the number of each type of renewable energy policy in a given country in a given year.

Certain control variables were also included in the model, which may also have influenced the development of renewable capacities. These included the country's gross domestic product, carbon dioxide intensity, electricity consumption, long-term interest rates, and stock indices.

Regional Statistics, Vol. 10. No. 2. 2020: 166-185; DOI: 10.15196/RS100207 
As the impact of individual renewable policies is delayed in some cases, a longitudinal analysis has also examined the impact of policies on the development of renewable capacities with some time lag. Thus, a measure introduced up to three years ago has also been considered to have resulted in a renewable capacity surplus in the given year.

Summarising the results of the regression analysis, it can be said that out of the fiscal-financial incentives, feed-in-tariff support has the maximum positive impact on renewable capacity investment in the case of aggregated renewable data, wind, and above all, solar sectors. Among the countries examined, this effect was the most significant in Germany and Italy. The strong positive correlation is primarily due to feed-in-tariff schemes providing a guaranteed return over time, thereby reducing the risk of renewable energy investments.

The analysis concluded that technology-specific policies are favourable for renewable energy investments, considering the current state of the renewable market and the maturity of the technology. Investors prefer financial incentives that are predictable in the long term (e.g. feed-in-tariff system) rather than support schemes that depend on political periods and the budget (e.g. tax breaks, favourable loans). However, it should be noted that investment subsidies and favourable loans play a very important role in diffusing the technology during its early stages. The introduction of market incentives can only be beneficial for more mature renewable technologies.

Lüthi (2010) examined the German, Spanish, and Greek markets with an empirical analysis for photovoltaic solar power plants, investigating why Mediterranean countries with better irradiation exposure did not develop more solar capacity than Germany, which has lower irradiation levels. It was concluded that above a certain level of return, revenue-oriented installation factors (such as the amount of the feed-in-tariff) no longer influence the investment decision, rather risk. factors (such as stability of the support system or administrative barriers) become important determinants of investment decisions.

The solar market in each country was examined based on revenue-oriented (e.g. tariff rate, duration of support, and solar energy potential) and risk factors (e.g. support policy stability, support limit, and administrative processes), based on expert interviews.

The empirical analysis concluded that all three countries, especially Spain and Greece, perform well in terms of revenue-oriented factors. Therefore, if we examine only these factors, the Spanish and Greek solar markets should be at least as advanced as the German market. However, political risks (e.g. administrative obstacles, difficulties in network connection, and risk of sudden political changes) has greatly influenced the development of the solar market.

In Germany, the Renewable Energy Sources Act has created a stable investment environment, the administrative processes are relatively fast and transparent, and the network connection process is well regulated. This has led to a multiplication of the

Regional Statistics, Vol. 10. No. 2. 2020: 166-185; DOI: 10.15196/RS100207 
installed solar capacity in the country, especially since the introduction of the feedin-tariff system, despite the less favourable irradiation conditions than in the Mediterranean countries.

Based on the reviewed international literature, it can be concluded that renewable policies, including renewable support schemes (e.g. feed-in-tariff and premium), have a significant impact on the geographical location of renewable technology investments. These policies directly influence the producer's revenue and indirectly impact the investment environment by stabilising the support systems, administrative processes, and other political factors, which indirectly influence the installation decision (see Polzin et al. 2015, Lüthi 2010). This is the reason for countries with less favourable natural conditions but more constructive renewable energy policies (e.g. Germany) being able to build higher renewable capacities than regions with better potential (see e.g. Lüthi's analysis of photovoltaic solar power plants).

As mentioned earlier, the international literature we have reviewed also examined the impact of subsidies on the installation decision in the case of wind farms. In our opinion, these results can also provide useful information on the location of solar power plants. Therefore, we briefly summarise the key points below.

According to empirical studies (e.g. Hitaj et al. 2014), the feed-in-tariff system had a significant positive impact on the development of wind power capacity in Germany. Some authors (see also Hitaj et al. 2014) opine that the spatial location of wind farms was affected by the location-specific feed-in-tariff support system in a manner that if it had not been introduced (i.e. a location-neutral tariff had been applied), then much more wind farms would have been built in the North German provinces. In contrast, there are models (see Jägemann 2014) that argue for technology and location-neutral forms of support.

In the case of a premium system, spatial location affects wind farms' revenues, as many studies (e.g. Schmidt et al. 2013, Pechan 2017) have supported the so-called merit order effect, according to which increasing wind power production will lower market prices. According to Schmidt, this means that wind farms will be more spatially differentiated, although he did not consider the impact of network congestions in the analysis. In contrast, Pechan (2017), Obermüller (2017), and Hiroux-Saguan (2010) included the cost of network integration into the analysis. They concluded that premium support would only lead to system-wide spatial optimisation of renewable energy sources, including wind farms, if nodal pricing is used. This implies that in addition to marginal production costs, network costs are also reflected in market prices. 


\section{Questionnaire description and research methodology in the Hungarian context}

In March 2018 we conducted a questionnaire survey among domestic renewable electricity producers, including solar power plants, in order to identify their installation criteria. The questionnaire was sent to the operational domestic renewable power plants on 10 March 2018, which totalled 305 power plant sites with a combined installed power capacity of $861 \mathrm{MW}$. In terms of the number of units, solar power plants accounted for the largest number (151 units) with an installed capacity of $111 \mathrm{MW}$.

The response rate was $38 \%$ based on the number of organisations and $39 \%$ based on the built-in capacity. This response rate can be considered representative based on the research performed.

In terms of the number of respondents and their installed capacity, solar power plants had the highest response rate (over 50\%), with 86 responses out of the 151 solar power plants surveyed. In terms of energy source, solar power plants have the highest representation: this is where the best correlation can be found between the distribution of those questioned and those responding.

The distribution of respondents was also examined according to different relevant categories (company size, power plant size, experience in the energy sector, and company type).

The answers to the questions were evaluated using Excel, R, and SPSS statistical programmes, based on the built-in statistical functions (frequency, average, and expected value calculation).

The Mann-Whitney test was used to determine if the difference between the scores given by the two respondent groups (yes/no and below or above 250 persons) was significant, as the values to be examined were not normally distributed. In cases where the frequency of occurrence was also an important criterion, and when normality and the standard deviation was not equal, we used the $Z$-test.

More than 40 installation factors were identified in the questionnaire. Therefore, cluster creation was a reasonable choice - to reduce dimension number, facilitate analysis, and increase transparency.

Given that we received a sufficient number of responses only in the case of solar power plants, clusters based on statistical calculations were also developed here. The groupings thus formed were applied to the other types of renewable power plants.

Regional Statistics, Vol. 10. No. 2. 2020: 166-185; DOI: 10.15196/RS100207 
Installation factors have been grouped into the following categories:

- Natural factors (e.g. meteorology and topographic factors);

- Location-specific factors (e.g. transport, energy infrastructure, proximity to consumers, and power plants);

- Economic factors (e.g. costs and revenues, payback time, and IRR);

- Financial support (e.g. level of support and predictability of support system);

- Environmental, social factors (e.g. administrative procedures, relationships, environmental impacts, and social acceptance).

Absolute (average of respondents' ratings per question) and relative order have been used to evaluate the answers. In the latter case, the five most important installation factors of the surveyed renewable power plants were selected and ranked. In such a case, it is not only important which aspect is ranked among the top five but also where its position lies. This was accomplished by assigning weights to the criteria in each rank: in the first place, five weights per respondent were ordered to the selected aspect; in the second place, four weights per respondent were ordered to the selected aspect, and so on. In the end, we summed up the weights for each question and sorted the questions in order.

It should be noted that due to respondents' errors and the structure of the questionnaire, some respondents selected the main category of installation factors instead of a concrete installation factor. Even in the case of non-financial support, some respondents mentioned an installation factor belonging to the financial support main category. These respondent errors were filtered by excluding incorrect answers from the analysis. This method was used for all renewable technologies.

\section{Results for solar power plants}

As mentioned earlier, solar power plants had the highest response rate: more than half $(57 \%)$ of the respondents filled out the questionnaire. Out of the 86 responding solar power plants, only 7 had an installed capacity of more than $0.5 \mathrm{MW}$, indicating that most were small power plants with no licensing obligation. Most of the responding solar power plants $(79 \%)$ were micro-enterprises with less than 250 employees. The vast majority $(99 \%)$ did not belong to consolidated groups of companies. Generally, these solar power plants did not have previous energy experience $(72 \%)$.

In absolute order, economic factors were predominant among the five most important installation factors (Figure 2). However, a location-specific factor (energy infrastructure) was also included (second place). According to the respondents, the most important factor was the marketability and price of the electricity/heat produced. Payback time and IRR were also relevant. Interestingly, an environmental/social factor (social responsibility) was the fifth most important installation factor. Solar power plant

Regional Statistics, Vol. 10. No. 2. 2020: 166-185; DOI: 10.15196/RS100207 
investors with previous experience in the energy sector tended to focus more on economic factors.

Figure 2

The five most important factors considered by solar power plants in the course of installation (absolute order, average of respondent ratings)

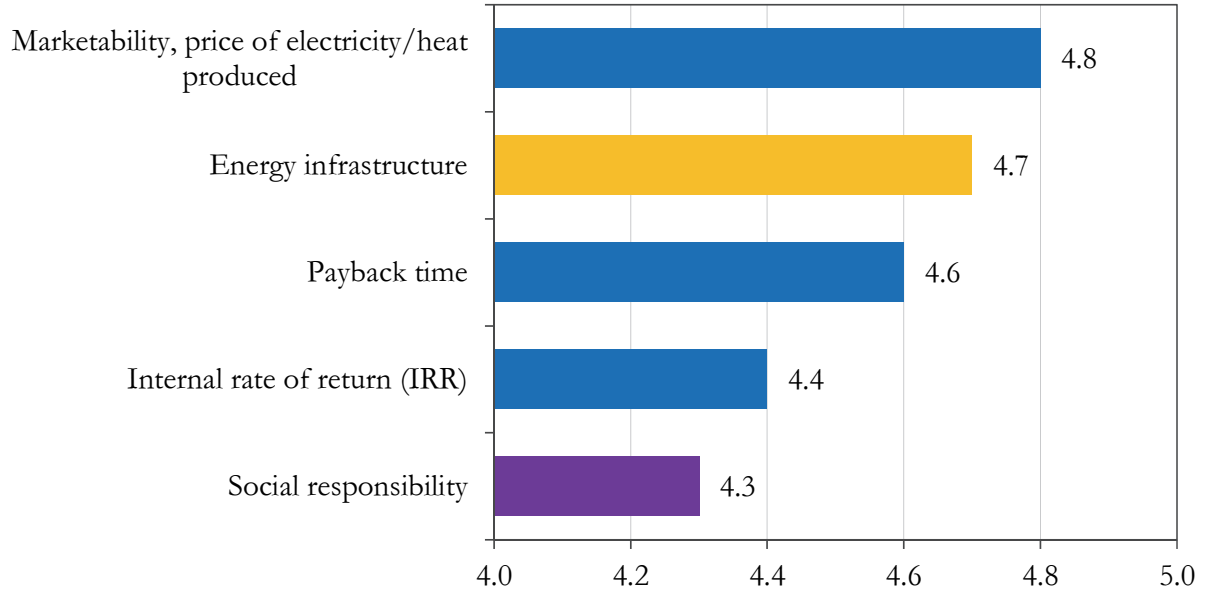

Notes: Colour coding: yellow - location-specific factors; blue - economic factors; purple - environmental and social factors.

Source: Based on own survey (March 2018).

Solar power plant operators considered natural and location-specific factors less important than expected (on average 2.5 points for both groups of factors). Among the locationspecific factors, only energy infrastructure and land availability were considered to be of significant importance. The cost of renting land received only 1.99 points on average; however, when split based on installation capacities above and below 0.5 MW, the former received 4.29 points and the latter only 1.99 points. This difference is due to the relatively large space requirements of solar power plants.

Within natural factors, meteorological factors and available energy sources are bardly considered important. This can be explained by the geographical size of Hungary, where the meteorological characteristics (e.g. number of sunshine hours) of each region are similar.

Economic factors received an average rating of 2.6. The most important economic factors were marketability/price of the electricity/heat produced, payback period, and IRR. The cost of network connection received a slightly higher than average rating. Due to the need for technological seed capital, investment-related costs and return on investment opportunities were considered important in cases where the marketability and price of the electricity / heat produced were extremely critical.

Within the financial support category, respondents emphasised the predictability and long-term sustainability of the financial support system (evaluated on average at 4.2). The availability 
and amount of (soft) loans, credit costs, and financial subsidies received a higher than average (3.7) rating. More important than the amount of financial support was the predictability of the system in the hope of a solid return on investment.

On average, environmental and social factors were rated at 2.7. The most important environmental and social factor was social responsibility. The relationship with local governments, as well as the duration and complexity of administrative procedures and licensing were rated higher than average.

Other installation factors included the avoidance of shading effects and the special nature of the installation area (archaeological site, high gold crown value, especially suitable, e.g. re-cultivated slurry pond). One respondent mentioned that his place of birth also determined his decision, that is, personal motivation also appeared as a factor influencing the location of the installation (Dusek 2013).

Out of 86 responding solar power plant operators, 14 tested nationwide for installation. There is a much higher proportion among those who had already been engaged in energy activities before the given venture (50\%). Nevertheless, the majority of respondents examined the middle regional level for implementing the investment.

For solar power plants, the five most important installation factors are shown in Figure 3, based on the relative (weighted) order of the installation factors.

Figure 3

\section{Relative order of installation factors for solar power plants (sum of weights)}

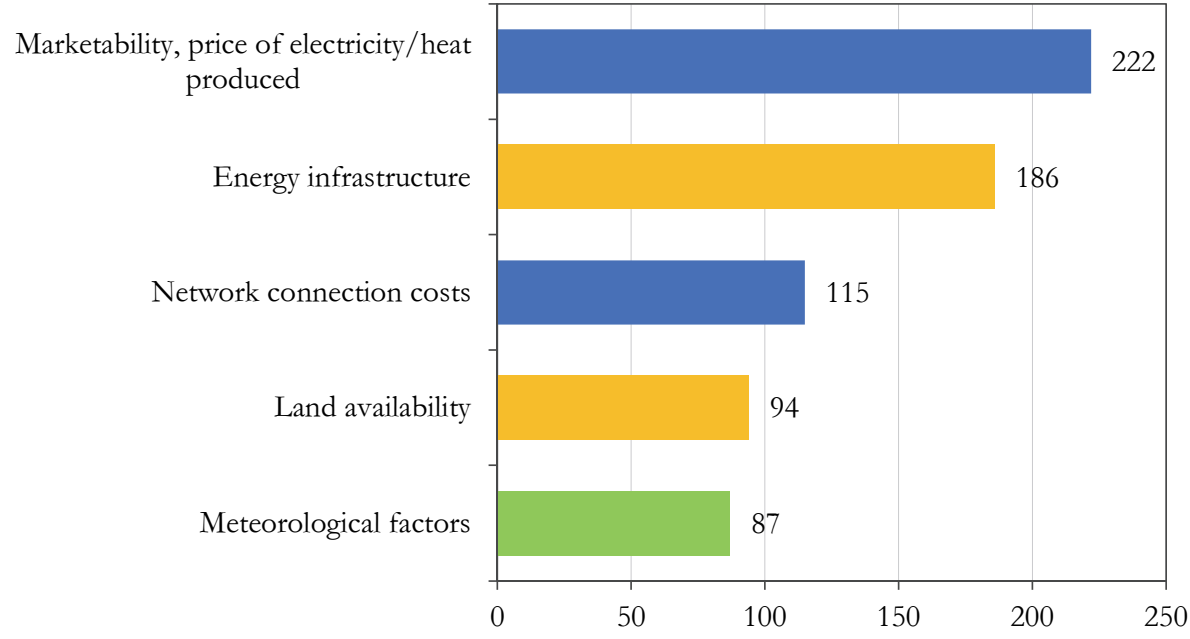

Notes: Colour coding: green - natural factors; yellow - location-specific factors; blue - economic factors. Source: Based on own survey (March 2018). 
Compared to the absolute order, there is no difference in the order of aspects in the first two places: not only the main category of installation factors but also the specific installation factors are the same. The third-place has a cost factor, although here it is the cost of network connection instead of payback time in absolute order. Instead of the IRR as an economic factor, a location-specific aspect - the availability of land - was at the fourth place (as mentioned earlier, the installation of solar power plants requires space). The fifth-place had a natural factor, namely the meteorological aspects (e.g. irradiation).

For companies with prior experience in the energy sector, network connection cost was the most important installation factor, while for inexperienced companies, the marketability and price of the electricity produced were of primary concern. In the case of experienced companies, meteorological factors were ranked second, while in the case of inexperienced companies, this factor did not even rank among the top five. Another highlighted factor is the energy infrastructure, which ranked only 5th for experienced companies, while it ranked second for companies with no previous energy experience. While the cost of network connection was one of the five most important installation factors for solar power plants with an installed capacity below $0.5 \mathrm{MW}$, for power plants above $0.5 \mathrm{MW}$ capacity, this factor was not included in the top five. The relative order of energy infrastructure, availability of land, and meteorological factors are similar within the two groups. For capacities above $0.5 \mathrm{MW}$, the second most important factor was the IRR, and for those below $0.5 \mathrm{MW}$, it only had an average weight. For larger solar power plants, the marketability and price of the electricity produced was the primary installation factor, while for smaller solar power plants it was the availability of energy infrastructure.

As the financial support category was the most important installation factor group for the solar power plants surveyed, it is worth examining the impact of financial subsidies on the order of importance of the installation factors. It should be noted that those solar power plants that responded to the questionnaire usually received operating support and soft loans.

A total of 47 solar power plants provided the relative order of factors in case of no financial support. Figure 4 illustrates the deviations from the relative order with financial support by the frequency of mentions. Without financial support, social responsibility would have been less important and would not have been among the top five installation factors. Energy infrastructure and marketability/price of the electricity produced were the two most important factors in both cases, although the ranking would have been reversed had the responding solar power plants not received financial support. Furthermore, without financial support, meteorological factors would have been more important, and placed among the top five installation factors.

Regional Statistics, Vol. 10. No. 2. 2020: 166-185; DOI: 10.15196/RS100207 
Relative order of installation factors for solar power plants with and without financial support (frequency of mentions)

\section{With financial support}

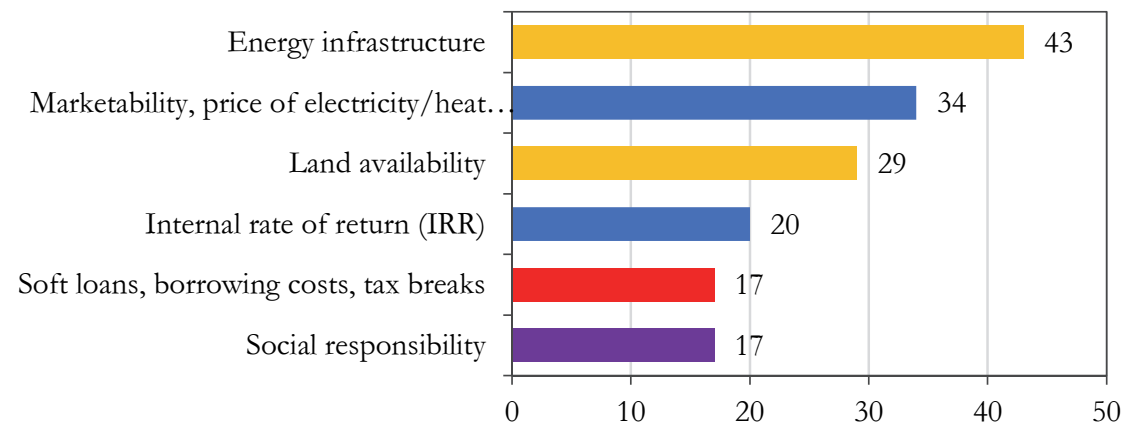

Without financial support

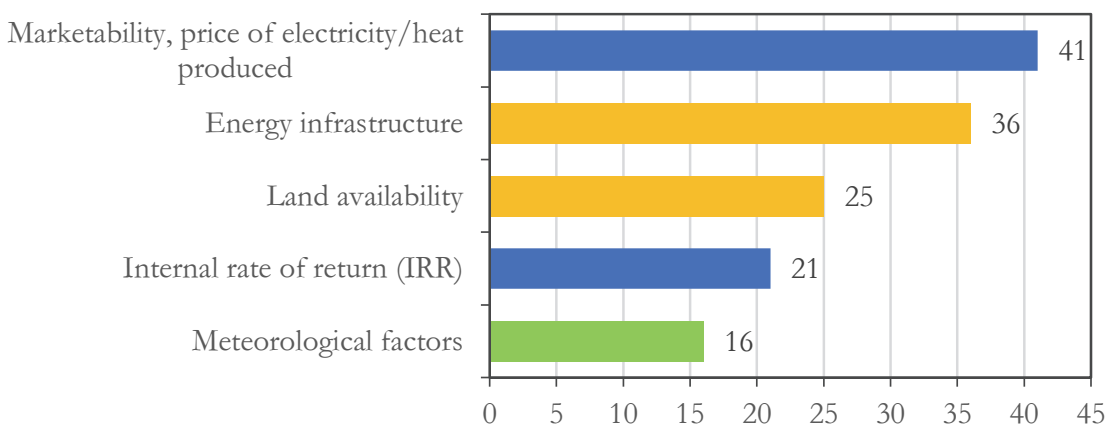

Notes: Colour coding: green - natural factors; yellow - location-specific factors; blue - economic factors; red financial support; purple - environmental and social factors.

Source: Based on own survey (March 2018).

In the case of aspects where the greatest differences were observed with and without financial support regarding the frequency of mentions, Z-test ${ }^{5}$ was performed to confirm the significance of the difference.

Statistically justifiable differences:

- In the absence of financial support, meteorological factors are more important than with financial support.

- Without financial support, energy infrastructure and environmental standards are less important than with financial support.

${ }^{5}$ https://www.socscistatistics.com/tests/ztest/Default2.aspx

Regional Statistics, Vol. 10. No. 2. 2020: 166-185; DOI: 10.15196/RS100207 
Statistically non-justifiable difference:

- There is no statistically significant difference in the importance of the availability of land with and without financial support.

An examination of the impact on the weighted ranking of installation factors reveals that in the absence of financial support, marketability and price of electricity produced is more important than energy infrastructure. The cost of network connection would not even appear in the top five rankings without financial support and would be replaced by the payback period (Figure 5).

Figure 5

\section{Relative order (weighted ranking) of installation factors for solar power plants with and without financial support (sum of weights) \\ With financial support}

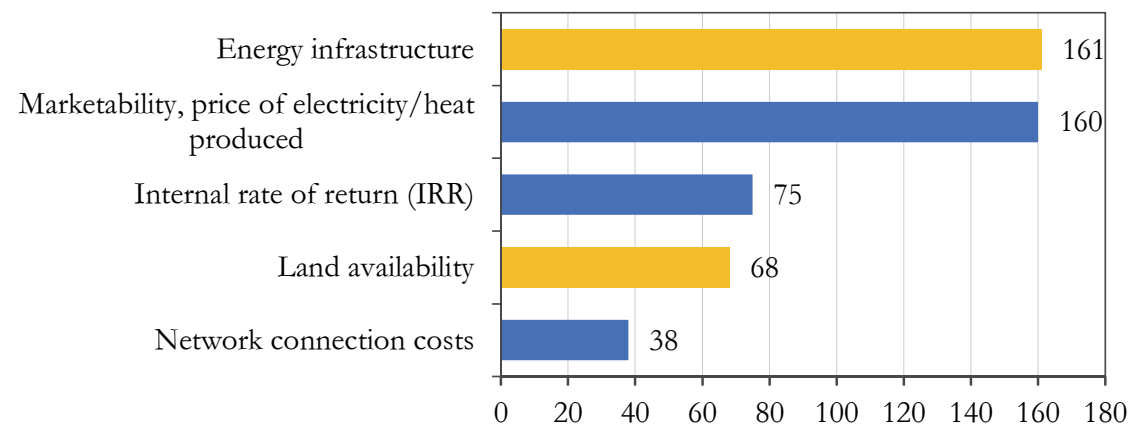

\section{Without financial support}

Marketability, price of electricity/heat produced

Energy infrastructure

Internal rate of return (IRR)

Land availability

Payback time

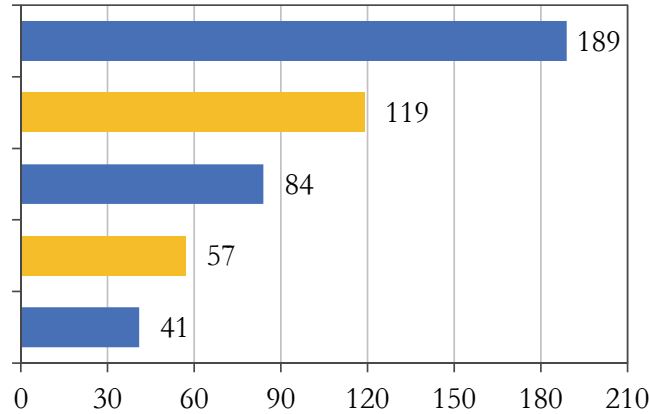

Notes: Colour coding: yellow - location-specific factors; blue - economic factors.

Source: Based on own survey (March 2018).

Regional Statistics, Vol. 10. No. 2. 2020: 166-185; DOI: 10.15196/RS100207 


\section{Conclusions}

Our research objective was to identify the installation factors that domestic renewable power plants, especially solar power plants, consider important when making an investment decision, and how this investment decision is influenced by the existence of financial support. From a domestic perspective, the topic of the study can be considered as novel in relation to the spatial aspects of financial subsidies to renewable electricity generation. To date, no similar study has been conducted for Hungary, presumably because no major disturbances in the electricity system have occurred hitherto in connection with renewable electricity production.

On the one hand, our results show that interestingly, the most important factors influencing the installation of solar power plants are not natural factors (e.g. irradiation) but marketability, price, and network connection (energy infrastructure) of the produced electricity, both in terms of absolute and relative order. This may be due to the small geographical size of Hungary, where the meteorological characteristics (e.g. number of hours of sunshine) of each region are similar. In addition, the predictability of the financial support system and the amount of financial support is critical for solar power plant investment decisions.

As most solar power plants are included in the feed-in-tariff system, marketability of the electricity produced (that is, guaranteed acceptance by the transmission system operator) and its price (that is, the feed-in-tariff) can be considered, in our opinion, as installation factors in the financial support category. Therefore, it can be stated that the existence of operating support was the most important installation factor in the case of solar power plant investments.

Secondly, without financial subsidies (mainly operating support for solar power plants), investors would strive to maximise revenues (that is, selling electricity at higher prices or making better use of environmental factors) and minimise losses (e.g. choosing the network connection point as close as possible or searching for cheap land). Thus, operating support influences other aspects of the site selection process, their order of importance, and through this, the site selection process itself. Therefore, operating support can influence the location of the renewable power plant installation, which can be used as valuable information by the regulator in case of further expansion of domestic renewable capacities, especially the intermittent solar power generation in Hungary.

Our research should be pursued and widened in two directions: on the one hand, by repeating the questionnaire survey among (producing) solar power plants already operating at a given time, as this would provide more information on the site selection criteria (given that there were more than 1,400 solar power plant producers by the end of 20196). This survey could also explore possible installation effects of the premium scheme introduced in 2017. The other direction of research could be the examination of location-specific subsidies.

${ }^{6}$ Source: Hungarian Energy and Public Utility Regulatory Authority.

Regional Statistics, Vol. 10. No. 2. 2020: 166-185; DOI: 10.15196/RS100207 
Annexes

The most important installation factors for solar power plants

Annex 1

\begin{tabular}{|c|c|c|}
\hline Author & Grouping aspect & Installation factor \\
\hline \multirow{8}{*}{ Liu et al. (2017) } & \multirow{3}{*}{ Geographical features } & Irradiation \\
\hline & & Altitude \\
\hline & & Temperature \\
\hline & \multirow{4}{*}{ Economic factors } & Investment costs \\
\hline & & Operational costs \\
\hline & & Revenues \\
\hline & & Outage costs \\
\hline & Environmental factor & Carbon dioxide emission avoidance rate \\
\hline \multirow{9}{*}{ Lee et al. (2017) } & \multirow{3}{*}{ Costs } & Land purchase/lease costs \\
\hline & & Module costs \\
\hline & & Maintenance and repair costs \\
\hline & \multirow{2}{*}{ Biological environment } & Land use \\
\hline & & Population density \\
\hline & \multirow{2}{*}{ Physical environment } & Soil quality \\
\hline & & Weather \\
\hline & \multirow{2}{*}{ Economic development } & Impact on agriculture \\
\hline & & Future capacity expansion opportunities \\
\hline \multirow{7}{*}{$\begin{array}{l}\text { Azevedo et al. } \\
\text { (2017) }\end{array}$} & Climatic factor & Direct normal irradiation \\
\hline & Topographic factor & Surface elevation \\
\hline & Environmental factor & Land use \\
\hline & \multirow{4}{*}{ Location factors } & Distance from electricity networks \\
\hline & & Distance from water bases \\
\hline & & Distance from major routes \\
\hline & & Distance from populated areas \\
\hline \multirow{15}{*}{$\begin{array}{l}\text { Al Garni et al. } \\
\text { (2017) }\end{array}$} & \multirow{2}{*}{ Environmental factors } & Land use \\
\hline & & Agrological capacity \\
\hline & \multirow{7}{*}{ Location factors } & Distance from populated areas \\
\hline & & Distance from electricity substations \\
\hline & & Population density \\
\hline & & Distance from major road networks \\
\hline & & Distance from electricity networks \\
\hline & & Distance from sites of historical importance \\
\hline & & Distance from nature reserves \\
\hline & \multirow{2}{*}{ Economic factors } & Land price \\
\hline & & Construction costs \\
\hline & \multirow{2}{*}{ Climatic factors } & Irradiation \\
\hline & & Average temperature \\
\hline & \multirow{2}{*}{ Topographic factors } & Surface elevation \\
\hline & & Orientation \\
\hline \multirow{8}{*}{$\begin{array}{c}\text { Sánchez-Lozano et } \\
\text { al. (2015) }\end{array}$} & Environmental factor & Agrological capacity \\
\hline & \multirow{3}{*}{ Topographic factors } & Surface elevation \\
\hline & & Orientation \\
\hline & & Surface features of the site \\
\hline & \multirow{4}{*}{ Location factors } & Distance from major routes \\
\hline & & Distance from electricity networks \\
\hline & & Distance from cities \\
\hline & & Distance from electricity substations \\
\hline
\end{tabular}

Regional Statistics, Vol. 10. No. 2. 2020: 166-185; DOI: 10.15196/RS100207 
Financial subsidies and the location decision of solar power plants in Hungary: An empirical investigation

The most important installation factors for solar power plants (continued)

\begin{tabular}{|c|c|c|}
\hline Author & Grouping aspect & Installation factor \\
\hline \multirow{13}{*}{ Ayag (2015) } & \multirow{6}{*}{ Geographical factors } & Cost of earthworks \\
\hline & & Number of hours of sunshine \\
\hline & & Irradiation \\
\hline & & Wind force \\
\hline & & Air pollution \\
\hline & & Precipitation amount \\
\hline & \multirow{3}{*}{ Economic factors } & Energy cost \\
\hline & & Government support \\
\hline & & Land price \\
\hline & \multirow{4}{*}{ Social factors } & Workforce availability \\
\hline & & Safety \\
\hline & & Social acceptance \\
\hline & & $\begin{array}{l}\text { Contribution to the economic development of the } \\
\text { region }\end{array}$ \\
\hline \multirow{5}{*}{ Uyan (2013) } & \multirow{2}{*}{ Environmental factors } & Distance from populated areas \\
\hline & & Land use \\
\hline & \multirow{3}{*}{ Economic factors } & Distance from roads \\
\hline & & Surface elevation \\
\hline & & Distance from electricity transmission networks \\
\hline \multirow{11}{*}{$\begin{array}{l}\text { Carrión et al. } \\
\text { (2008) }\end{array}$} & \multirow{2}{*}{ Environmental factors } & Land use \\
\hline & & Visual impact \\
\hline & \multirow{2}{*}{ Topographic factors } & Surface elevation \\
\hline & & Orientation \\
\hline & \multirow{3}{*}{ Location factors } & Distance from major routes \\
\hline & & Distance from electricity substations \\
\hline & & Distance from populated areas \\
\hline & \multirow{4}{*}{ Climatic factors } & Global radiation \\
\hline & & Diffuse radiation \\
\hline & & Number of hours of sunshine \\
\hline & & Average temperature \\
\hline
\end{tabular}

Source: Edited by Tóth (2019)

Regional Statistics, Vol. 10. No. 2. 2020: 166-185; DOI: 10.15196/RS100207 
Annex 2

A summary of international literature on the effects of renewable subsidies on the location of renewable power plants

\begin{tabular}{|c|c|c|c|c|c|}
\hline Author & $\begin{array}{l}\text { Level of } \\
\text { analysis }\end{array}$ & $\begin{array}{c}\text { Locational } \\
\text { factors examined }\end{array}$ & $\begin{array}{c}\text { Renewable } \\
\text { technologies } \\
\text { included in the } \\
\text { study }\end{array}$ & $\begin{array}{l}\text { Analysis/model } \\
\text { type }\end{array}$ & Main conclusion \\
\hline $\begin{array}{l}\text { Polzin et al. } \\
(2015)\end{array}$ & $\begin{array}{l}\text { Global } \\
\text { (OECD } \\
\text { countries) }\end{array}$ & $\begin{array}{l}\text { Renewable } \\
\text { policies (finan- } \\
\text { cial, market, } \\
\text { regulatory } \\
\text { incentives) }\end{array}$ & $\begin{array}{l}\text { All renewable } \\
\text { technologies }\end{array}$ & $\begin{array}{l}\text { Panel regression } \\
\text { analysis }\end{array}$ & $\begin{array}{l}\text { Feed-in-tariff } \\
\text { systems have the } \\
\text { greatest impact on } \\
\text { renewable } \\
\text { investments. }\end{array}$ \\
\hline Lüthi (2010) & $\begin{array}{l}\text { Regional } \\
\text { (German, } \\
\text { Greek, } \\
\text { Spanish) }\end{array}$ & $\begin{array}{l}\text { Income-oriented } \\
\text { factors } \\
\text { risk factors }\end{array}$ & $\begin{array}{l}\text { Solar power } \\
\text { plants }\end{array}$ & $\begin{array}{l}\text { Empirical analysis } \\
\text { based on } \\
\text { historical data }\end{array}$ & $\begin{array}{l}\text { Risk factors are } \\
\text { more important } \\
\text { than revenue- } \\
\text { oriented factors. }\end{array}$ \\
\hline $\begin{array}{l}\text { Hitaj et al. } \\
(2014)\end{array}$ & $\begin{array}{l}\text { Local } \\
\text { (Germany, } \\
\text { county level) }\end{array}$ & $\begin{array}{l}\text { Feed-in-tariff } \\
\text { support }\end{array}$ & Wind farms & $\begin{array}{l}\text { Econometric } \\
\text { model }\end{array}$ & $\begin{array}{l}\text { Feed-in-tariff } \\
\text { support has a } \\
\text { significant } \\
\text { positive and } \\
\text { timely impact on } \\
\text { the development } \\
\text { of wind power } \\
\text { capacity. }\end{array}$ \\
\hline $\begin{array}{l}\text { Jägemann } \\
(2014)\end{array}$ & \multirow{5}{*}{$\begin{array}{l}\text { National level } \\
\text { (Germany and } \\
\text { Austria) }\end{array}$} & $\begin{array}{l}\text { Marginal cost, } \\
\text { limit value, net } \\
\text { marginal cost } \\
\text { (marginal cost } \\
\text { minus limit } \\
\text { value) of certain } \\
\text { renewable } \\
\text { technologies }\end{array}$ & $\begin{array}{l}\text { All renewable } \\
\text { technologies }\end{array}$ & $\begin{array}{l}\text { Electricity } \\
\text { optimisation } \\
\text { model }\end{array}$ & $\begin{array}{l}\text { Technology and } \\
\text { region-neutral } \\
\text { renewable } \\
\text { subsidies lead to a } \\
\text { socially cost- } \\
\text { effective } \\
\text { renewable power } \\
\text { plant location. }\end{array}$ \\
\hline $\begin{array}{l}\text { Schmidt et al. } \\
(2013)\end{array}$ & & $\begin{array}{l}\text { Feed-in-tariff } \\
\text { and premium } \\
\text { support }\end{array}$ & \multirow{4}{*}{ Wind farms } & $\begin{array}{l}\mathrm{NPVa}_{-} \\
\text {optimisation } \\
\text { model, regression } \\
\text { model }\end{array}$ & $\begin{array}{l}\text { Premium systems } \\
\text { encourage site } \\
\text { diversification of } \\
\text { wind farms. }\end{array}$ \\
\hline $\begin{array}{l}\text { Pechan } \\
(2017)\end{array}$ & & $\begin{array}{l}\text { Feed-in-tariff, } \\
\text { premium or } \\
\text { network conges- } \\
\text { tions (single vs. } \\
\text { nodal pricing) }\end{array}$ & & $\begin{array}{l}\text { General Algebraic } \\
\text { Modelling System }\end{array}$ & $\begin{array}{l}\text { Only nodal priced } \\
\text { premium systems } \\
\text { promote the site } \\
\text { diversification of } \\
\text { wind farms. }\end{array}$ \\
\hline $\begin{array}{l}\text { Obermüller } \\
\text { (2017) }\end{array}$ & & $\begin{array}{l}\text { Feed-in-tariff, } \\
\text { premium or } \\
\text { network } \\
\text { congestions } \\
\text { (single vs. nodal } \\
\text { pricing) }\end{array}$ & & $\begin{array}{l}\text { Electricity } \\
\text { optimisation } \\
\text { model }\end{array}$ & $\begin{array}{l}\text { Nodal pricing and } \\
\text { regionally } \\
\text { differentiated } \\
\text { feed-in-tariffs } \\
\text { promote the site } \\
\text { diversification of } \\
\text { wind farms. }\end{array}$ \\
\hline $\begin{array}{l}\text { Hiroux- } \\
\text { Saguan } \\
(2010)\end{array}$ & & $\begin{array}{l}\text { Market signals } \\
\text { (e.g. nodal, zonal } \\
\text { pricing, } \\
\text { intraday/ day- } \\
\text { ahead trading) }\end{array}$ & & Empirical analysis & $\begin{array}{l}\text { Enabling intraday } \\
\text { and day-ahead } \\
\text { trading, as well as } \\
\text { nodal and zonal } \\
\text { pricing, affect the } \\
\text { location of wind } \\
\text { farms. }\end{array}$ \\
\hline
\end{tabular}

Source: Tóth (2019)

a) Net Present Value.

Regional Statistics, Vol. 10. No. 2. 2020: 166-185; DOI: 10.15196/RS100207 


\section{REFERENCES}

Al GARni, H. Z.-AwASTHI, A. (2017): Solar PV power plant site selection using a GIS-AHP based approach with application in Saudi Arabia Applied Energy 206: 1225-1240. https://doi.org/10.1016/j.apenergy.2017.10.024

Azevedo, V.-CANDEIAS, A. L. B.-TiBA, C. (2017): Location study of solar thermal power plant in the state of Pernambuco using geoprocessing technologies and multiplecriteria analysis Energies 10 (7): 1042. https://doi.org/10.3390/en10071042

Carrión, J. A.-Estrella, A. S.-Dols, F. A.-Toro, M. Z.-RodrígueZ, M.-RidaO, A. R. (2008): Environmental decision-support systems for evaluating the carrying capacity of land areas: Optimal site selection for grid-connected photovoltaic power plants Renewable and Sustainable Energy Reviews 12 (9): 2358-2380. https://doi.org/10.1016/j.rser.2007.06.011

DusEK, T. (2013): Tér és közgazdaságtan L’Harmattan Kiadó, Budapest.

HitAJ, C.-SCHYMURA, M.-LÖSCHEL, A. (2014): The impact of a feed-in tariff on wind power development in Germany ZEW - Centre for European Economic Research Discussion Papers 14-035, Leibniz. http://dx.doi.org/10.2139/ssrn.2457779

Hiroux, C.-SAGUAN, M. (2010): Large-scale wind power in European electricity markets: Time for revisiting support schemes and market designs? Energy Policy 38 (7): 3135-3145. https://doi.org/10.1016/j.enpol.2009.07.030

JäGEMANN, C. (2014): Essays on the Economics of Decarbonization and Renewable Energy Support. PhD thesis, Universität zu Köln. https://kups.ub.uni-koeln.de/5666/

Kyriakarakos, G.-Patlitzianas, K.-Damasiotis, M.-Papastefanakis, D. (2014): A fuzzy cognitive maps decision support system for renewables local planning Renewable and Sustainable Energy Reviews 39: 209-222. https://doi.org/10.1016/j.rser.2014.07.009

LEE, A. H. I.-KANG, H-Y.-LIOU, Y-J. (2017): A hybrid multiple-criteria decision-making approach for photovoltaic solar plant location selection Sustainability 9 (2): 184. https://doi.org/10.3390/su9020184

LiU, J.-XU, F.-LiN, S. (2017): Site selection of photovoltaic power plants in a value chain based on grey cumulative prospect theory for sustainability: A case study in Northwest China Journal of Cleaner Production 148: 386-397.

https://doi.org/10.1016/j.jclepro.2017.02.012

LÜTHI, S. (2010): Effective deployment of photovoltaics in the Mediterranean countries: Balancing policy risk and return Solar Energy 84 (6): 1059-1071. https://doi.org/10.1016/j.solener.2010.03.014

Merrouni, A.-Elalaoui, F. E.-Mezrhab, A.-Mezrhab, A.-Ghennioui, A. (2018): Large scale PV sites selection by combining GIS and analytical hierarchy process. Case study: Eastern Morocco Renewable Energy 119: 863-873. https://doi.org/10.1016/j.renene.2017.10.044

Regional Statistics, Vol. 10. No. 2. 2020: 166-185; DOI: 10.15196/RS100207 
MülleR-FrĄCZEK, I. (2019): Dynamic measurement of complex phenomena in assessing the Europe 2020 strategy effects Regional Statistics 9 (1): 32-53.

https://doi.org/10.15196/RS090107

Obermüller, F. (2017): Build Wind Capacities at Windy Locations? Assessment of System Optimal Wind Locations. EWI Working Papers 2017-9, Energiewirtschaftliches Institut an der Universitaet zu Koeln (EWI)

Pechan, A. (2017): Where do all the windmills go? Influence of the institutional setting on the spatial distribution of renewable energy installation Energy Economics 67: 75-86. https://doi.org/10.1016/j.eneco.2017.04.034

Polzin, F.-Migendt, M.-Täube, F. A.-VOn Flotow. P. (2015): Public policy influence on renewable energy investments. A panel data study across OECD countries Energy Policy 80: 98-111. https://doi.org/10.1016/j.enpol.2015.01.026

SÁnCHEZ-LOZANO, J. M.-GARCÍA-CASCALES, M. S.-LAMATA, M. T. (2015): Evaluation of suitable locations for the installation of solar thermoelectric power plants Computers \& Industrial Engineering 87: 343-355. https://doi.org/10.1016/j.cie.2015.05.028

SCHMidT, J.-LEHECKA, G.-GASS, V.-SCHMID, E. (2013): Where the wind blows: Assessing the effect of fixed and premium based feed-in tariffs on the spatial diversification of wind turbines. Energy Economics 40: 269-276. https://doi.org/10.1016/j.eneco.2013.07.004

UYAN, M. (2013): GIS-based solar farms site selection using analytic hierarchy process (AHP) in Karapinar region, Konya/Turkey Renewable and Sustainable Energy Reviews 28: 11-17. https://doi.org/10.1016/j.rser.2013.07.042

\section{INTERNET REFERENCES}

AGORA ENERGIEWENDE (2019): The European power sector in 2018. Up-to-date analysis on the electricity transition Sandbag-Agora Energiewende, London-Berlin. https://www.agora-energiewende.de/fileadmin2/Projekte/2018/EUJahresauswertung_2019/Agora-Energiewende_European-Power-Sector2018_WEB.pdf (downloaded: May 2020)

AYAG, Z. (2015): A multiple-criteria decision making method for evaluating solar power plant location alternatives Proceedings of the 9th International Management Conference Management and Innovation for Competitive Advantage, Bucharest. http://conference.management.ase.ro/archives/2015/pdf/93.pdf (downloaded: May 2020)

Regional Statistics, Vol. 10. No. 2. 2020: 166-185; DOI: 10.15196/RS100207 
Financial subsidies and the location decision of solar power plants in Hungary: An empirical investigation

IRENA (2019): Renewable capacity bighlights

https://www.irena.org/-

/media/Files/IRENA/Agency/Publication/2019/Mar/RE_capacity_highlights_ 2019.pdf?la=en\&hash=BA9D38354390B001DC0CC9BE03EEE559C280013F (downloaded: May 2020)

MagyarorszÁg KormánYa (2020): Nemz̨ti Energiastratégia 2030, kitekintéssel 2040-ig. Tisz̧ta, okos, megfizethetö Energia Budapest.

https://www.kormany.hu/download/b/40/c1000/Strat\%C3\%A9gi\%C3\%A1k_ 20200116.zip\#! (downloaded: May 2020)

TóтH, T. (2019): A zöld erömüvek területi elhelyezkedését befolyásoló telepitési tényezőo, különös tekintettel a müködési támogatásokra Széchenyi István Egyetem Regionális- és Gazdaságtudományi Doktori Iskola Doktori (Phd) értekezés tervezet - kézirat https://rgdi.sze.hu/downloadmanager/index/id/9911/m/12743 (downloaded: May 2020)

Regional Statistics, Vol. 10. No. 2. 2020: 166-185; DOI: 10.15196/RS100207 